\title{
Editorials
}

\section{New editor of the Archives}

It is a great pleasure to welcome Dr S R Meadow as the new joint editor of the Archives. Roy Meadow is Senior Lecturer in the Department of Paediatrics and Child Health at the University of Leeds. He is a general paediatrician with a specific interest in paediatric nephrology, but his view of paediatrics is broadly based. He is an enthusiastic teacher, and his writings include joint authorship of a highly successful textbook for undergraduates. As secretary to the Academic Board of the BPA he was largely responsible for having the various specialist sub- groups set up or brought within the Association. This development is acknowledged to have been one of the most successful in the BPA in recent years, and it has enhanced the interest and scientific content of the Annual General Meeting. It is a good example of Roy Meadow's interest and vision in paediatric communication and education-qualities which will be a great asset to the Archives. We wish him a long, happy, and successful time in the editorial chair.

R J R 